\title{
A Business Model Design for the Strategic and Operational Knowledge Management of a Port Community
}

\author{
Felisa Córdova · Claudia Durán
}

Received: 2 June 2014 / Revised: 30 July 2014 / Accepted: 5 September 2014 /

Published online: 8 October 2014

(C) Springer-Verlag Berlin Heidelberg 2014

\begin{abstract}
The community modality how middle and small size ports work, consists of a group of associative enterprises and logistic chains. In order to optimize the efficiency of their activities at both strategic and operational levels, they require a continuous assessment of their knowledge management. Accordingly, this work proposes a business model design for managing a sea port community. Firstly, the mission and the strategic objectives for such a community are defined. Then, the main strategic lines are classified correspondingly to the Balance Scorecard approach, using indicators as: efficiency, operational excellence, profitability, integration, social responsibility, and added value to the environment. Strategic and operational efficiency indicators are designed not only for improving the company and port management but also to gain competitive advantages.
\end{abstract}

Keywords Port community - Export/import logistic chains - Business model · Strategic management · Operational management · Efficiency indicators

\section{Introduction}

Ports that work a community network are composed of associative enterprises and logistic chains, involving a multiplicity of actors, each developing its own physical and informative flow. Among them: port companies, outer ports, port terminals, cities, and public and private organizations that support export and import activities. These actors are related in the same value chain i.e. service rendering-playing different

\footnotetext{
F. Córdova $(\varangle) \cdot$ C. Durán

Department of Industrial Engineering, University of Santiago de Chile,

Ecuador 3769, Santiago, Chile

e-mail: felisa.cordova@usach.cl

C. Durán

e-mail: claudia.duran@usach.cl
} 
roles, and having their own objectives, purposes, goals, and business plans. On the other hand, these agents require continuous evaluation of their management work to optimize the effectiveness of their activities at both strategic and operational levels. The Administrators of these ports, together with licensees, operating there as a result of port privatization, are among the main actors. All of them constitute a logistic chain, called extended or global, when their tackle activities are carried out for the importer/exporter from/to the ship $[8,12,14]$.

However, belonging to the same port community, a collaborative effort is imposed on them and every actor participating in the community, at the same time, calling from them such a coordination of actions that harmonic development, efficiency and effectiveness of their joint activities become evident.

But, within this context, these organizations seem not to be using adequate management tools that allow them to carry out an adequate monitoring and control of their activities, so they may not accurately evaluate or project their objectives and action plans; neither can they compare their business results—at the strategic level—with other ports at the national or international level $[1,2,7]$. Consequently, actors in most middle and small size ports don't have a clear idea about the required improvements that must take place to make them agree with the international standards of efficiency and effectiveness. Therefore, a quantitative evaluation of the socioeconomic impact of port activities in the city where it is located, is rarely found $[9,13,16]$. It then becomes necessary for these port communities to count on tools to help them improve their competitiveness, not only at the national but also at the international level.

On the other hand, there is no administration of tacit knowledge (experience, skills, expertise, and training) and neither is there access, through already automated and available means, to all the necessary explicit knowledge. In fact, each agent participating in the community exchanges knowledge verbally, not leaving any necessary reports to assure continuity to his/her management, especially in times of high personnel turnover. This means that every time a management change occurs, new knowledge must be created instead of using the existing and available information [5,6,11]. It is then necessary to transmit and socialize the information and knowledge that have been created and acquired so that all the agents participating in the community can share this business knowledge.

\subsection{Business Model and Actors in the Port System}

The port consists of a group of self-help organizations that operate independently, but exchange information between them. Port activity is represented by a community of companies gathered in a logistic forum which is an instance of joining all companies participating as actors in the exchange of foreign trade. This forum aims to achieve full integration, facilitating and pursuing excellence in each process, through the development of innovative solutions that contribute to the competitiveness of the port as the leader of the national and international industry. This entity gathers very diverse actors associated with the Administration and port operation, and care for the political, financial, economic and social aspects that are generated. The purpose of this community is to have representatives at the regional level to sustain conversations for action to solve problems. Not all the actors involved in the Logistics Forum exchanged information 
related to the efficiency and effectiveness of operations, which for the most part is implied. The actors who could manage the knowledge in this area are the Port Authority, Internal Port Terminal, Externalized Port Terminals and Previous Logistic Zones.

Associative companies form a port community composed of actors of which only a few exchange non-elaborated information knowledge. These actors, who are not integrated into a business model that generates a collaborative system for sharing information produced at strategic and operational levels, also lead the logistic chains and the development of the information systems used by the other actors in the port system.

\section{Materials and Methods}

\subsection{Main Actors in the Port System}

The Port community, whose knowledge transfer is done through conversations, is composed of a port authority and other related actors as described below.

\subsection{Port Company}

It is the main company because it plays the role of port authority that leads the port community. The Port Company is autonomous from the Government and is the owner of its facilities according to productivity indicators of CEPAL [3]. It generates and manages information concerning the efficiency and effectiveness of the logistics activities of the port community. It also manages the information provided by The Internal Port Terminal, Externalized Port Terminals and Previous Logistic Zones. The Port Company uses its own software of electronic forms to record data from the activities carried out on a daily basis. However, this software neither allows knowledge management nor allows collaborative work. It has management tools of knowledge that help control their activities but which cannot be accurately assessed or projected, turning this into a difficult task to figure out what improvements should take place.

\subsection{Internal Port Terminal}

It only provides the infrastructure of the port terminals. It is not under concession and is operated by the Port Company under a multi-operator scheme. It does not have heavy machinery and presents physical and structural limitations. It acts as a buffer for intermediate storage which allows the management of different types of cargo from export and import. Its activities are planned and directed by the Port Company and the cargo moving jobs are dealt by outsource private enterprises.

\subsection{Externalized Port Terminals}

These are private companies in charge of the administration and operation of port terminals, performing maritime/port services linked to the ship and the merchandise. 

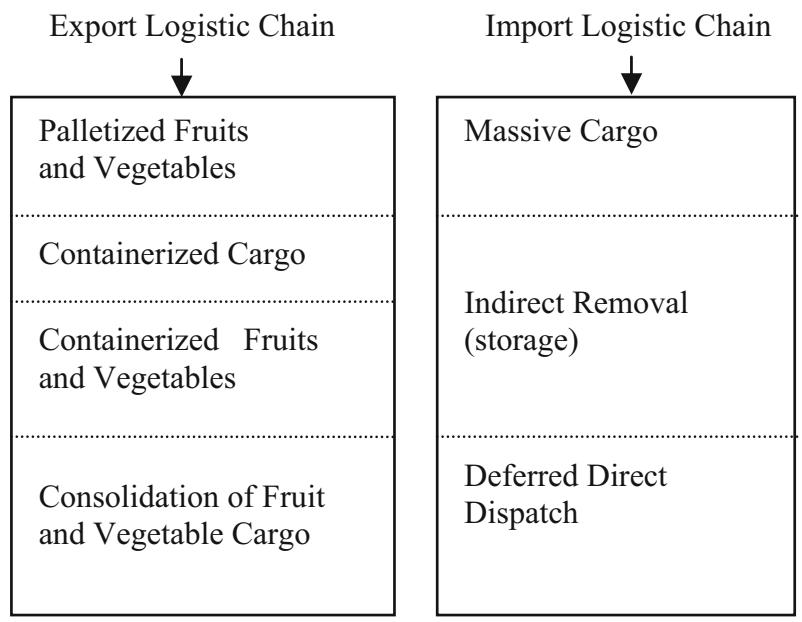

Fig. 1 Export and import logistic chains

They have fixed and mobile equipment: different capacity cranes, tractor trucks, and others.

\subsection{Previous Logistic Zone}

This is a zone under concession where a private company, working as an outer port, carries out logistic activities to increase the productivity of the ports. They also use technologies for improving the operational efficiency of transporters and terminals.

The actors of the port system based on the knowledge management, are part of logistic chains of export and import. These chains correspond to the set of companies that ensure that the import/export process is fulfilled completely. Export chains are classified according to the type of load: Palletized Fruits and Vegetables, Containerized Cargo, Containerized Fruits and Vegetables, Consolidation of Fruits and Vegetable charge. Import chains are also classified by type of cargo: Massive Charge, Indirect Removal and Deferred Direct Dispatch. These chains correspond to the set of companies that ensure that the import/export process is fulfilled completely. The companies that make up these chains are in some cases competitors among themselves, these kinds of chains which are representative of the kind of cargo used in a particular kind of port (Fig. 1).

Each and every actor-Internal Port Terminal, Externalized Port Terminals and Previous Logistic Zones-does not keep records, either of the existing tacit knowledgeexperience, skills, expertise and training — or the explicit knowledge, being unable to produce any reports on performance assessment (Fig. 2).

In this way, each manager in every company transmits knowledge verbally to his/her employees and workers. Even, they do not count on any software to prepare the necessary reports to make knowledge explicit and to allow the continuity of his/her administration, having to create new knowledge every time a new management takes office. 


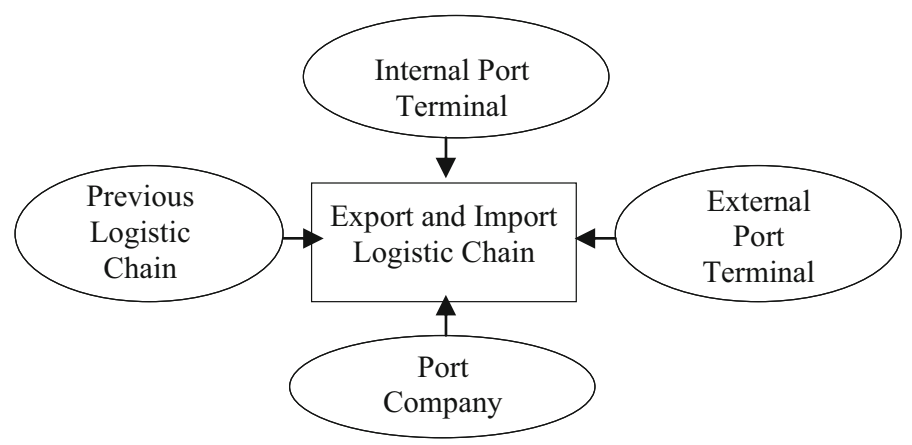

Fig. 2 Actors and logistic chains

Previous Logistic

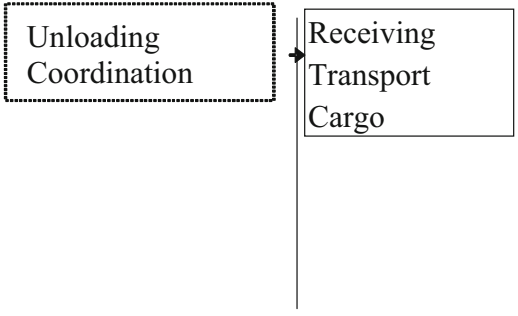

Terminal

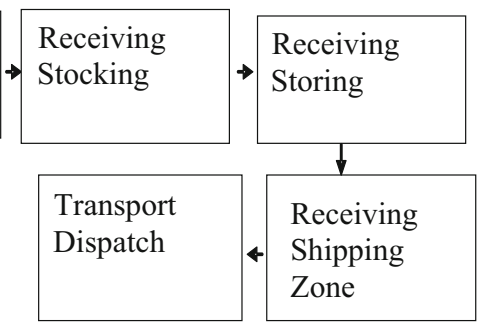

Fig. 3 Internal port terminal sub processes of the export logistic chains

It is necessary then, to make information available so that other people can acquire the knowledge of the business to start a collaborative work.

It is important to point out that these sub-processes involve activities that must be measured and which jointly generate indicators that can be shared by the actors of the port community (Figs. 3, 4, 5, 6, 7 and 8).

With regard to the efficiency and effectiveness of logistics chains, the information is handled through the documentation required to export and import.

This is not elaborated information since the actors do not have management reports to measure the process. In this way there are delays that cannot be measured because of a lack of indicators and indices at strategic and operational levels.

\subsection{Mission and Strategic Lines of a Middle Size Generic Port (MSGP)}

A middle size generic port is a port of medium size which is composed of public actors and private members of a port community. The main actor is the port playing the role of port authority, which is a public organization that leads the port community. Port authority is linked to the development of infrastructure, administration and management of the generic port; it acts as regulator, establishes rules and regulations for the port community [4]. Private actors build superstructures, facilities, providing port services linked to the industrial and logistics activity. 


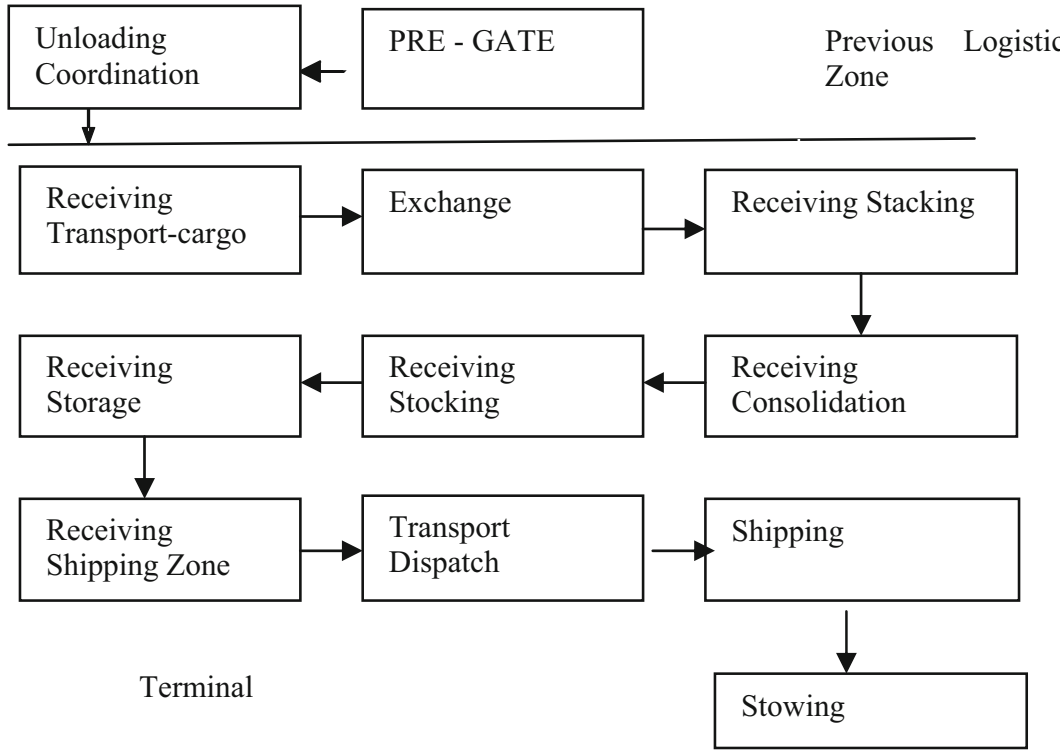

Fig. 4 Externalized port terminal sub processes of the export logistic chains

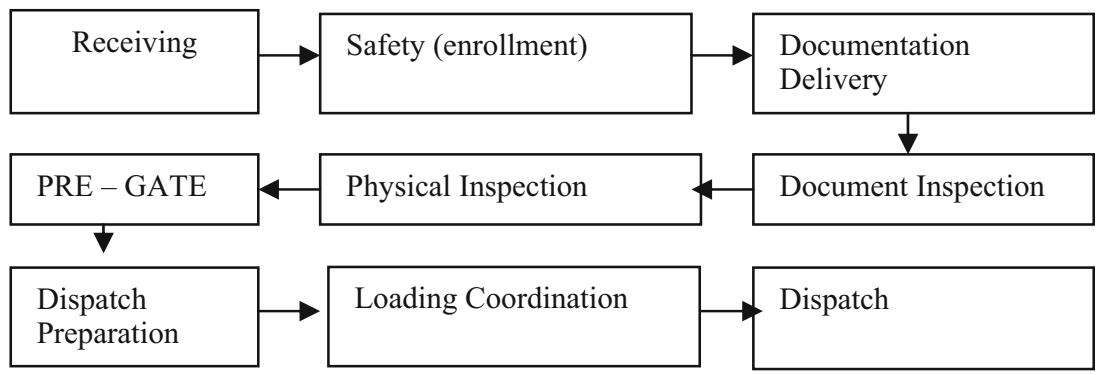

Fig. 5 Previous logistic zone sub processes of the export logistic chains

Previous Logistic

Zone
Terminals

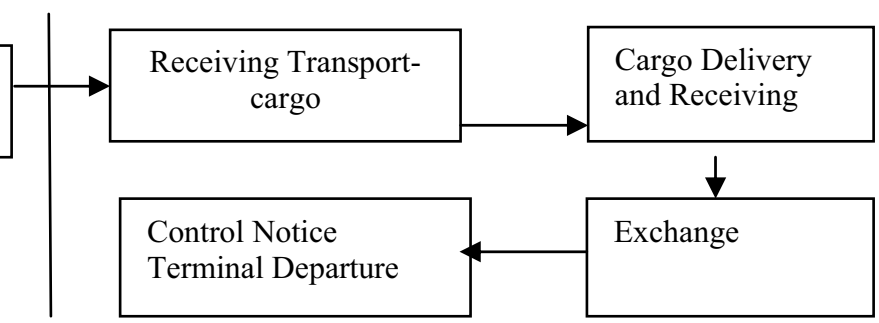

Fig. 6 Port terminal sub processes of the import logistic chains 
Previous Logistic

Zone
Terminals

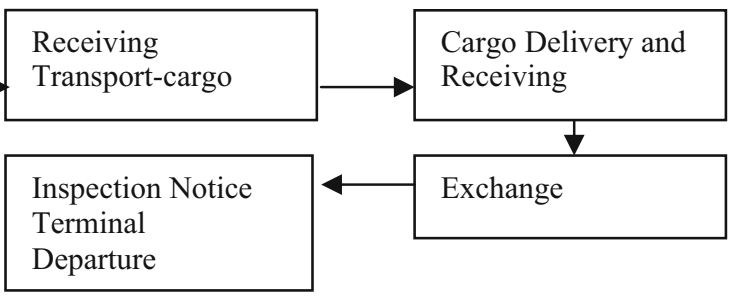

Fig. 7 Externalized port terminal sub-processes of the import logistic chains

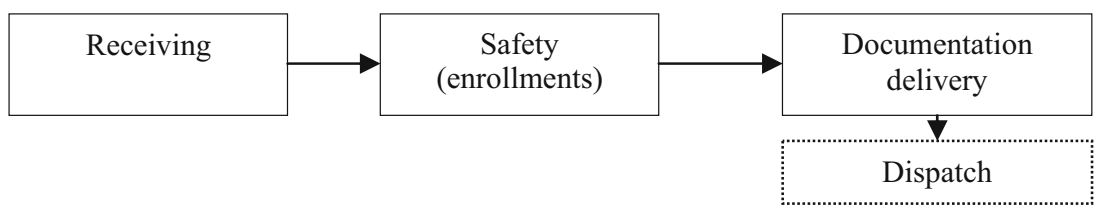

Fig. 8 Previous logistic zone sub-processes of the import logistic chains

A Middle Size Generic Port (MSGP) has a mission that reflects the organizational purposes and its leadership with respect to its clients and the delivery of products and/or services [15]. The Mission of the MSGP is to:

- Minimize the contribution to the generalized transport cost.

- Maximize the generation of added value.

- Carry out port activities in a sustainable way.

Its Mission contains the following strategic lines:

- Value to the environment: traffic, logistic activity / industrial and business centre.

- Efficiency: cost to customer, productivity and operational excellence.

- Profitability: in relation to the port authority and service providers.

- Integration: environmental respectful Port - City relations; social responsibility for sustainable development.

According to the characteristics of the Balanced Scorecard the four perspectives for the classification of the strategic lines are considered [10].

- Financial: value to the environment and profitability.

- Client: value to the environment, efficiency and integration.

- Internal processes: value to the environment, efficiency and integration

- Learning and growth: value to the environment.

\subsection{Business Model}

The Mission of each Community actor that generates knowledge based on efficiency and effectiveness is: 
- Port Company and Internal Port Terminal: "Make the port attractive to the participants in the transport logistics chain, the investors, and the citizens. It must stand out, in the national and international port sector, for its infrastructure management, port facilitation, and sustainable development."

- Externalized Port Terminals: "Administrate and operate a Port Terminal."

- Previous Logistic Zones: "Integrate our clients' logistics chains by means of a cargo services platform, with high levels of quality, safety, innovation and technology oriented at facilitating international commerce in a harmonic setting aligned with the environment."

To form a single business model it is necessary to have a single mission that integrates the interests of the three actors. The missions of the actors are complementary so that a single mission can be established for the Port Community: "Make the port attractive to the participants in the transport logistics chain, the investors, and the citizens. It must stand out, in the national and international port sector, for its infrastructure management, its port facilities, and sustainable development. It must administrate and operate the Port with its Terminals, integrate the logistics chains of our clients by means of a cargo service platform, with high levels of quality, safety, innovation and technology oriented at facilitating international commerce in a harmonic setting aligned with the environment."

The Mission of the port community is related to the Mission of the generic port. Thus, the Mission of the actors of the port community with strategic lines and strategic objectives of the generic port can be associated with. The strategic objectives of the generic port can be classified and described according to each strategic line as shown below:

- Strategic Objectives for increasing value to the surroundings:

Grow up in traffic.

Increase competitiveness and port activity.

Maximize the productivity of the facilities and port operations.

Increase the logistics, industrial and business of the port activity.

- Strategic Objectives for increasing efficiency:

Increase the profitability of businesses operating in the port and the port authority.

Grow up in traffic.

Achieve customer loyalty by increasing logistics, industrial and business activity in the port.

Maximize the productivity of the facilities and port operations.

- Strategic Objectives for increasing profitability:

Optimize the management of operation and costs of investments, both services supply companies and the port authority.

Maximize the productivity of the facilities and port operations.

- Strategic Objectives for achieving integration:

Grow up in traffic.

The strategic goals of each stakeholder of the port community are described below: 
- Port Company: its purpose is to manage, exploit, develop and preserve the Port, as well as the goods that it owns, including all the related activities inherent to the port setting and indispensable for its fulfillment.

- Internal Port Terminal: its purpose is to provide the infrastructure of the associated terminals.

- Externalized Port Terminal: its purpose is the administration and operation of the associated terminal (sites under concession). It is designed for handling container and multipurpose ships, providing service to ship owners or shipping companies whose ships dock in the mooring wharf and offering cargo services such as storage, consolidation, deconsolidation, marking, resealing, classification, inventory control, cargo weighing, packing repairs, connection and monitoring of refrigerated containers, stowing, among others.

- Previous Logistic Zone: its objective is to be in charge of receiving, verifying, controlling, and coordinating the flow of cargo vehicles to and from the Port's docking front activities. It uses a Cargo Service Platform.

The strategic objectives of the generic port with the strategic objectives of the actors of the port community are associated with.

The perspectives in the context of the Balanced Scorecard allow to explain and to classify the Port Community strategy, [10]. There are two types of strategies: external and internal. External strategies correspond to the financial and customer perspectives; they represent the results of the acting of the Port Community. Internal strategies include the process and learning perspectives; the objectives from which the Port Community takes images for acting.

In the context of the Balanced Scorecard, the external and internal perspectives may relate to the strategic objectives of the generic port:

- Strategic objectives associated with the financial perspective:

Increase the profitability of businesses operating in the port and the port authority.

- Strategic objectives associated with the client perspective:

Grow up in traffic.

Achieve customer loyalty by increasing logistics, industrial and business activity in the port.

- Strategic objectives associated with the internal process perspective:

Optimize the management of operation and costs of investments, both of services supply companies and the port authority.

Maximize the productivity of the facilities and port operations; increase of logistics, industrial activity and business of the port.

- Strategic objectives associated with the learning and growth perspective:

Increase the competitiveness and the commitment of the actors with the port activity.

A business model for the previous logistics port area is proposed where its mission, strategic lines and strategic goals are associated with a generic port. It is possible to implement operational objectives, indicators from the strategic and operating indicators of the generic port to the port community. 


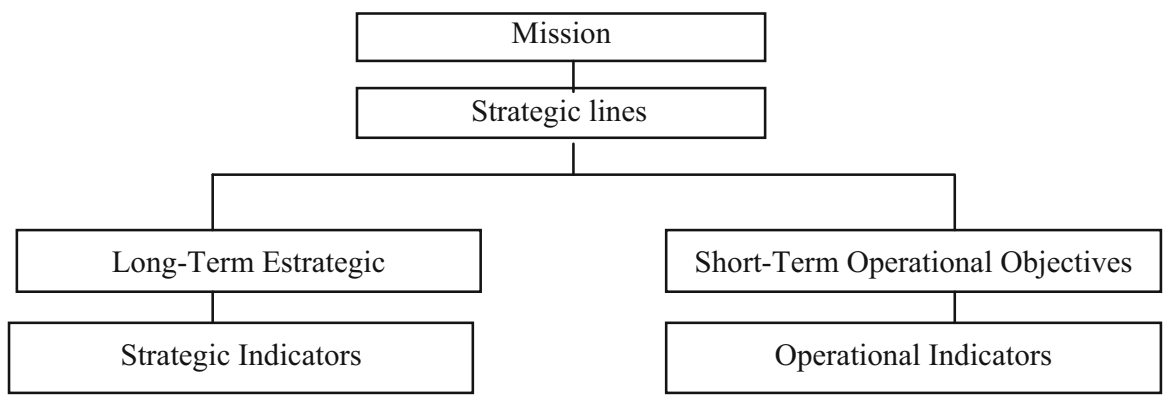

Fig. 9 Business model

Figure 9 presents the business model for the port with previous logistics area. To complete the business model, we just need to design indicators and indices of efficiency and added value for the port community based on knowledge generation.

\section{Results}

\subsection{Transformation of Strategic Indicators from a MSGP to a Port with Previous Logistic Zone}

The strategic objectives give rise to the strategic indicators, and the information is administered by the logistic actors. It must be pointed out that although there are other actors that generate information, only those that help transform the tacit-explicit knowledge achieving its socialization, externalization, combination, and internalization are considered [11].

The perspectives that classify the strategic lines are related to strategic objectives within the context of the Balanced ScoreCard. The exporter and the importer are considered as customers. The port is medium sized and does not have facilities for transferring bulk solid and liquid cargo. The port system has two terminals that have mooring lines that are divided into stations. Therefore the indicators to be considered are:

\subsection{Financial Perspective as Productivity Strategic Objective}

This objective is oriented at increasing the profitability of the companies that operate in the port and of the port authority. The information to calculate the indicators is obtained from the web page of the national agency that provides the financial information. The actors managing the information with which the indicators can be designed are: Port Company, Internal Port Terminal and Externalized Port Terminal.

- ROA of the Port Authority: it measures the annual variation (\%). It reflects how profitable the business is:

$$
\mathrm{ROA}=\frac{U d i}{I} \times \frac{A}{T A}=\frac{U P}{T A}
$$


where Udi is the earnings after taxes, I the income, A the assets, UP the fiscal year profit loss, TA the Total assets Land, buildings and machinery are considered as assets.

- Percentage of companies with EBITDA > 0 .

EBITDA: it is calculated with a company sample. It is not an accurate measurement, but it attempts to isolate the cash flow generation capacity of the company's operation.

$$
\begin{aligned}
\text { EBITDA }= & \text { earnings after taxes }+ \text { interest }+ \text { taxes }+ \text { amortization } \\
& + \text { depreciation } \\
= & \text { gross operational profit }- \text { depreciation } \\
& \quad-\text { amortization. Taxes are not included. }
\end{aligned}
$$

EBITDA greater than zero, is used to know if the company will go broke in the future, i.e., if cash is going into its current account.

\subsection{Objective Client's Perspective as Critical Success Factor: Growth in Traffic}

- Traffic turn over: measures the variation (\%) from one year to the next of cargo traffic by kind of merchandise.

Only general containerized, dry, and refrigerated cargo and fractionated cargo is transferred. General cargo includes containers and fractionated cargo, and it is measured in tons.

Information: the data of the cargo is saved on an Excel spread sheet.

- Gross added value (VAB) generated by the conventional port activity: the annual variation $(\%)$ of the VAB is measured.

$$
\begin{aligned}
\mathrm{VAB}= & \text { labor cost (includes social security) }+ \text { amortization of intangibles } \\
& + \text { result before income taxes and extraordinary items (profit or loss) } .
\end{aligned}
$$

Labor cost is confidential information of the company.

Information: amortization of intangibles and results before taxes are obtained from the web page of the Superintendence of Securities and Insurance. There is no information for Previous Logistic Zone. The nominal value is expressed in pesos.

\subsection{Objective Client's Perspective as a Value for the Client: Growth in Traffic}

- Market rate: The annual growth (\%) shows how fast a port grows, and whether it is efficient. The rate is measured by type of cargo (described in terms of traffic growth) monthly or annually.

$$
\text { Rate }=\frac{C l m}{C E x}
$$

where $\mathrm{CI}_{\mathrm{m}}$ is the imported cargo, $\mathrm{CE}_{\mathrm{x}}$ the exported cargo.

Information: the cargo data are saved on an Excel spreadsheet. 


\subsection{Objective Client's Perspective as a Value for the Client}

It is oriented at building customer loyalty by increasing logistic, industrial, and business activity in the port.

- Port traffic to the activity of the distribution centers and port industries: it measures customer loyalty building capacity $(\%)$ by type of cargo.

Information: the data on customer cargo are saved on Excel spreadsheets.

\subsection{Internal Processes Perspective as Operations Management Process}

It is oriented at optimizing the management of operational costs and investments of the Port Authority as well as of the service rendering companies (the second indicator is associated with the risk). The information for calculating the indicators is obtained from the web page of the national agency that provides financial information.

- Percentage of current expenses of the Port Authority over income (\%): it measures annually the percentage of what it sells that is converted into costs.

It should be mentioned that both the Port Terminal and the Externalized Port Terminal are the owners of their facilities (machinery and equipment), so an index must be calculated for the Port Terminal and another one for the Externalized Port Terminal. In the latter case the areas are under concession.

$$
\text { Index }=\frac{C \exp }{I \exp }
$$

where Cexp is the exploitation costs, Iexp the exploitation income

- Percentage of the amount of debt over liabilities of the Port Authority: annual indebtedness is measured (\%), long-term liabilities are used, which measure whether the company has long term debts. An index is calculated for the Port Company and another one for the Externalized Port Terminal.

$$
\text { Index }=\frac{\text { PasLP }}{\text { Patr }}
$$

where PasLP is the long term liabilities, Patr the total assets

\subsection{Learning and Growth Perspective as Strategic Information Capital}

It is oriented at increasing the competitiveness and commitment of port activity. The information to calculate the indicators is obtained from the web page of the national agency that provides financial information.

Result of the exploitation: it measures the annual result obtained from the operation of the business; this indicator serves only to see if the company has been doing well or not. 
3.8 Transformation of Operational Indicators and Indices of a Generic Port to a Port with a Previous Logistic Zone

Although it is true that the actors that enter the information are the Internal Port Terminal and the Externalized Port Terminal, it is the Port Company that transforms implicit into explicit knowledge through the preparation of reports and meetings. Those reports contain numerical data and information with qualitative analysis, and there are no indices that assist in Management Control. The indicators and indices in the context of the Balanced Scorecard are presented bellow.

\subsection{Objectives of the Internal Processes Perspective as Operation Management Process}

It is oriented to maximize the productivity of the facilities and port operations. Indicators relate to the efficiency and effectiveness of operations in terminals and are associated to logistics costs and at the time of delay in the terminals that affect the process of export and import. There are productivity indices that are measured as a function of the cargo transferred in TEUs and in tons.

Since there are two terminals, $i=1,2$.

- Mean terminal productivity index $(\%)=\frac{T S_{i}}{\sum T S_{i}}$

where TSi is the tonnage station $\mathrm{i}$

- Terminal productivity index $=\frac{T T E U_{i}}{T T E U_{1}+T T E U_{2}}$

where TTEUi is the terminal i TEUS

Total number of TEUs mobilized at the terminal per year/number of container wharfs.

- Productivity index of the ship at the terminal $=\frac{T T_{i}}{N S T_{i}}$

where TTi is the terminal $i$ tonnage, NSTi the number of ships terminal $i$

Average amount of cargo transferred per hour by the ship that it is moored at the terminal.

There are indices that measure the occupation time of the arrival of a ship at a terminal (hour/ship) (Fig. 10).

The indices related to time are:

- Waiting rate for a station $=\frac{W T}{S T}$

where WT is the waiting time for mooring station, ST the service time at the station. 


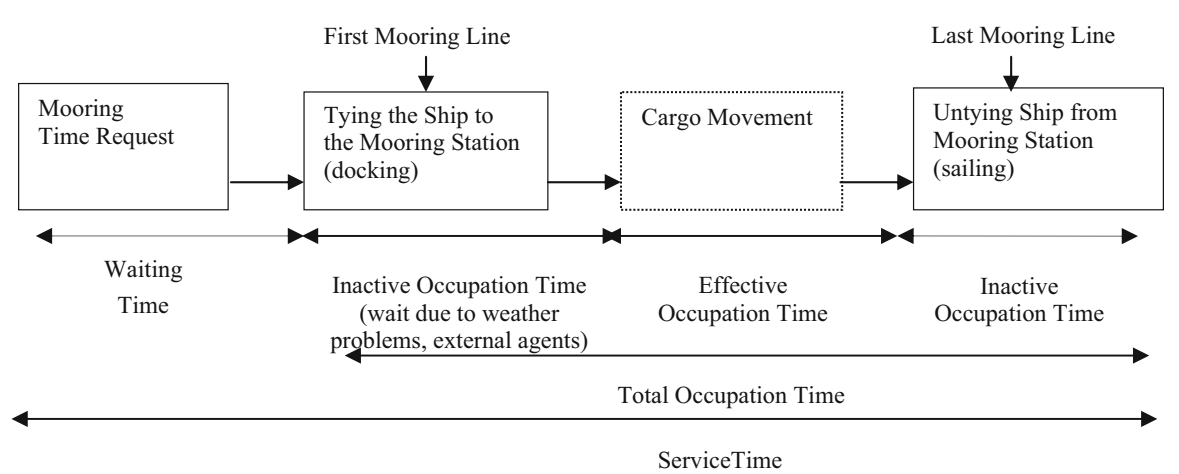

Fig. 10 Process of arrival time of a ship to the port terminal

Waiting time reasons: wait for available wharf, rain, early arrival of ship, wait for personnel, crane stoppage, port pilot or tug boat delay, ship repairs or maintenance, early termination of job, weather or tides, delayed arrival of ship, delay of stevedore's job, among others. It shows the congestion state.

- Annual waiting time (in hours) at terminal $=\frac{\sum F M T_{j}-R D T_{j}}{365^{*} 24^{*} 0,97}$

where FMTj is the first mooring tying time $\mathrm{j}, \mathrm{RDT} \mathrm{j}$ the required docking time $\mathrm{j}$, where $\mathrm{j}=1, \ldots, \mathrm{n}$ is the number of ships. Factor $0.97=$ at the company they calculate 97 $\%$ for availability and $3 \%$ for external factors (e.g., weather problems). It measures inactive occupation time.

- $\quad$ Rate of use of a terminal (hours) $=\frac{\sum E O T_{j}}{\sum\left(L M R_{j}-F M R_{j}\right)}$

where EOT $\mathrm{j}$ is the effective occupation time $\mathrm{j}, \mathrm{LMRj}$ the last mooring rope time $\mathrm{j}$, FMRj the first mooring rope time $\mathrm{j}$, where $\mathrm{j}=1, \ldots, \mathrm{n}$ is the number of ships.

- Rate of occupation of a terminal (hours) $=\frac{\sum\left(L M R_{j}-F M R_{j}\right)}{\sum\left(L M R_{j}-D R T_{j}\right)}=\frac{\sum G S T_{j}}{\sum A T_{j}}$

where DRT is the docking request time $\mathrm{j}$, GST $\mathrm{j}$ the gross ship time $\mathrm{j}$, ATj the available time at terminal $\mathrm{j}$, where $\mathrm{j}=1, \ldots, \mathrm{n}$ is the number of ships. All the ships are considered.

- Mean time of the ship at port (hours) $=\frac{T A O}{T N S}=\frac{\sum\left(L M R_{j}-F M R_{j}\right)}{T N S}$

where TAO is the total annual occupation time, TNS the total number of ships arriving in one year 
- Time at the wharf $=$ average $\sum\left(L M R_{j}-F M R_{j}\right)$

- Docking activity index $=\frac{T T P S}{O T P S}$

where TTPS is the total tons per ship, OTPS the occupation time per ship.

- $\quad$ Docking activity index per terminal $=\frac{\sum T T_{i}}{\sum T O T_{i}}$

where TOTi is the terminal $\mathrm{i}$ occupation time

- Docking activity index per docking line $=\frac{\sum M L T_{k}}{\sum O T M_{k}}$

where MLTk is the mooring line tonnage $\mathrm{k}$, OTMk the occupation time mooring line $\mathrm{k} . \mathrm{k}=1,2$. Two mooring lines are considered.

- Cargo activity index at the terminal $=\frac{\sum T T_{i}}{\sum E O T_{j}}$

- Cargo activity index per mooring line $=\frac{\sum M L T_{k}}{\sum E O T M_{k}}$

where EOTMk is the effective occupation time mooring line $\mathrm{k}$.

\subsection{Objectives of the Client Perspective as Value for the Client: Operational} Indicators of the Previous Logistic Zone Actor

In the context of the Balanced Scorecard, the internal processes perspective is related to the strategic objective of actor called Previous Logistic Zones. This actor contributes to the strategic objective that seeks to increase the logistical, industrial activity and business of the port community.

The previous logistics area coordinates its activities via e-mail, by phone and its own software.

Port authority is who gives different actors permission down to the terminal, and who maintains the registration of such data in the software. This software does not integrate information of the various actors, does not provide cooperative work and does not manage knowledge.

The actor associated with the previous logistics zone has no indicators to make the coordination of their logistics activities more efficient and effective.

The indicators are related to the delays produced, which turn the process slower. They start when the trucks arrive and end when they get permission to go to the port. Inefficiencies occur in: attention at the cabins when the trucks arrive, rejection of the trucks at the entrance because they do not have all the required information when they are controlled by Customs or state services. This activity may take them several hours and they can also be rejected. 
Regarding to information, it changes as the process advances. Customers enter information through the Web. It is then processed in a system belonging to the Previous Logistic Zone, where the time spent in the premises is recorded in detail, as well as whether they are authorized to continue with the following activity. Although the time is recorded on line in the Previous Logistic Zone and the port, phase lags occur between the time a job is requested and the time it takes place. This affects the trucks and the approval times by the Television Camera Control. The fact that keyboarding errors occur must be also considered.

Mean time indicators of a truck's permanence can be constructed: in the premises, until it is requested by the terminal, entry to the Previous Logistic Zone, until entry to the premises, and in the inspection zone. Mean time for Customs revision of a truck (it parks waiting for control until revision by Customs or Agricultural livestock Service SAG).

Mean delay time: the terminal requests a truck until the truck leaves the Previous Logistic Zone for the terminal, and the terminal requests a truck with all the attributes approved until the request to get to the terminal. Mean time: dispatch of a requested truck until it is approved by Television Camera Control and delay in notifying the driver until the exit from the premises. Rate indicators can be constructed: rejections of trucks at the entrance and of trucks in Customs or SAG, average attention at a cabin or GATE (daily or per shift), mean permanence time at the quay side for Customs control, approval of terminal request by Television Camera Control, and incidences (keyboarding error) for the total trucks that have entered. It corresponds to Indicator of average rejection frequency of a truck at the entrance.

Some indicators and indices are considered:

- Annual average length of stay of a truck in the enclosure (in hours)

$$
=\frac{\sum\left(T A T_{j}-T R T_{j}\right)}{24 * 365^{*} T T A}
$$

where TAT $\mathrm{j}$ is the time (hours) $\mathrm{j}$ for admission to the premises of a truck (after being authorized in the cabin), TRTj the time $\mathrm{j}$ (hours) in of the truck which is requested by the port terminal, TTA the total of trucks arriving at the compound in a year.

- Annual average length of stay of a truck from entering the previous logistics

$$
\text { zone up to the entrance to the enclosure (in hours) }=\frac{\sum\left(T I T_{j}-T I Z_{j}\right)}{24^{*} 365^{*} T T Z}
$$

where TITj is the time $\mathrm{j}$ (hours) of entry of a truck onto the previous logistics area, $\mathrm{TIZj}$ the time (hours) $\mathrm{j}$ it takes a truck to enter the site of the previous logistics area (after it is approved in the cabin), TTZ the total trucks arriving at the previous logistics area in a year (generated waiting lines).

$$
\text { - } \text { Rate of rejection of trucks in customs }=\frac{\sum T_{i}}{N T}
$$

where Ti is the truck i rejected trucks in customs in a year, NT the total number of trucks in customs in a year. 


\section{Discussion}

During the process of creating indicators, tacit knowledge was transformed into explicit knowledge (externalization) with the purpose of delivering tools that may help the Port Company Management Control to measure and compare itself with its closest competitor. To that end it was confirmed that the strategic objectives of a generic port can be applied in a particular case. The administration of the explicit knowledge that is used to calculate the indicators is stored at a virtual level in software and files.

The strategic indicators are made explicit, mostly, through the web page of the SVS, and those that are confidential in registers, being handled only by top executives (such as labor cost and the cargo requested by each client). There is tacit port information that is transmitted orally (business knowledge).

Tacit part lies in their understanding, since the information existing in the port may not be transformed into knowledge; a person with experience in the area is needed to explain what it is about. With respect to the indicators concerning the Previous Logistic Zone, they are not explicit but rather at the tacit level, such us the processed information which is not written but transmitted from experience.

It is recommendable for the company to make its knowledge explicit because this would help it to devise the tools for making decisions.

If rates are evaluated numerically, it is necessary to ensure that the index values from the actors who make up the business model, do not override each other or give erroneous results. If actors do perform in a cooperative manner making information or knowledge management transparent, they may compete with other ports in a more efficient way or may give rise to port community leadership.

Acknowledgments This work was supported by DICYT USACH Project. Universidad de Santiago de Chile.

\section{References}

1. Beresford A, Gardner B, Pettit S, Naniopoulos A, Wooldridge C (2004) The UNCTAD and WORKPORT models of port development: evolution or revolution? Marit Policy Manag 31(2):93-107

2. Clark X, Dollar D, Micco A (2004) A port efficiency, maritime transport costs, and bilateral trade. J Dev Econ 75:417-450

3. Cullinane K, Dong-Wook S, Ping J, Teng-Fei W (2004) An application of DEA windows analysis to container port production efficiency. Rev Netw Econ 3(2):184-206

4. De Langen P (2003) The port authority as cluster manager. In: Proceedings of the 2nd international conference on maritime transport and maritime history, Technical University of Catalonia, Barcelona, pp 67-84

5. Distefano E (2002) La gestión del conocimiento en la empresa. Las Tesinas de Belgrano, Facultad de Ciencias Económicas Licenciatura en Administración de Recursos Humanos

6. Firestone $\mathrm{J}$ (2001) Estimating benefits of knowledge management initiatives: concepts, methodology, and tools, knowledge and innovation. J KMCI 1(3):110-129

7. Fredouet Ch, Le Mestre P (2005) Network performance measurement as applied to maritime port communities. J Int Logist Trade 3(2):1-13

8. Heaver T, Meersman H, Moglia F, Van De Voorde E (2000) Do mergers and alliances influence European shipping and port competition? Marit Policy Manag 27(4):363-373

9. Kia M, Shayan E, Ghotb F (2000) The importance of information technology in port terminal operations. Int J Phys Distrib Logist Manag 30(3/4):331-344 
10. Kaplan R, Norton D (2007) The strategy maps: converting intangible assets into tangible outcomes. Harvard Business School Press, Boston

11. Nonaka I, Takeuchi H (1997) De KenniscreeÈ rende Onderneming, Hoe Japanse Bedrijven Innovatieprocessen in Gang Zetten (The Knowledge Creating Business Enterprise: How Japanese Companies start Innovative Processes), Schiedam

12. Notteboom T, Winkelmans W (2001) Structural changes in logistics: how will port authorities face the challenge? Marit Policy Manag 28(1):71-89

13. Ojala L (1992) Modeling approaches in port planning and analysis. Publications of the Turku School of Economics and Business administration. Series A-4: 119

14. Pallis A (2003) Strategies to enhance Mediterranean EU Ports Competitiveness. In: Proceedings of the 2nd international conference on maritime transport and maritime history, Technical University of Catalonia, Barcelona, España, November 2003, pp. 107-120

15. Porter M (1996) What is strategy?. Harvard Business Review, Boston

16. Savall H (2003) An updated presentation of the socio-economic management model. J Organ Chang Manag 16(1):33-48

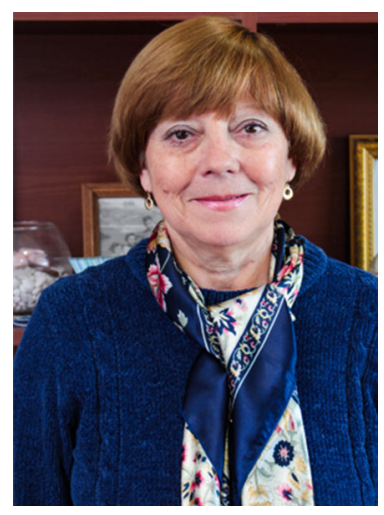

Felisa Córdova is Electrical Engineer at the University of Santiago of Chile USACH. She obtained the Diplome d'Etudes Approfondis and the degree of Docteur Ingénieur at the University of Paris XI, Centre d'Orsay, France (1981). Now she is professor and was Director of the Department of Industrial Engineering at the Faculty of Engineering of USACH, she was also Academic Vice Rector at USACH. Her main research interest is in the Business Strategy and in the Operations Management, also in Knowledge Management of the Supply Chain. She has participated in several national and international research projects in the fields of Robotics, AGV and Virtual Operation Systems in underground mining. She has published many papers in conference proceedings and international journals in the area of Robotics and Production Research. She is past-president of the Chilean Association of Automatic Control ACCA (member of IFAC). She has participated in the organization of national and international Conferences (ACCA, LCA, LCR, SEPROSUL, ICPR, CESA). She is national councilor and past Vice President of the College of Engineers of Chile, she is also member of the accreditation board of AcreditaCI.

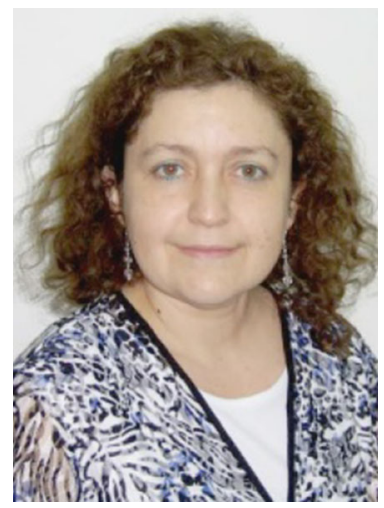

Claudia Durán graduated as Industrial Engineer at the School of Engineering of the Faculty of Physical Sciences and Mathematics at the University of Chile. She received a Master in 2011 and now studies (C) PHD in Industrial Engineering at the Department of Industrial Engineering of University of Santiago of Chile. Currently she is Professor and Coordinator courses of economy, Faculty of engineering, Department of Industrial Engineering. His research interests includes knowledge management, corporate governance strategies, relationship in business, management models, relations publicprivate of actors in maritime ports. 